\title{
Ratio Decidendi Putusan Hakim Yang Mengabaikan Laporan Penelitian Kemasyarakatan Dalam Perkara Anak (Studi Putusan Nomor: 38/Pid.Sus-Anak/2019/Pn.Kdi)
}

\author{
Ratio Decidendi Judge's Decision Who Ignored The Social Inquiry \\ Report In The Case Of Children (Decision Study Number: \\ 38/Pid.Sus-Anak/2019/PN.Kdi)
}

\author{
Teguh Pratiknyo \\ Kasubsi Bimbingan Klien Anak Bapas Kelas II Kendari \\ E-mail: teguh.pratiknyo@gmail.com \\ Herman \\ Pascasarjana Universitas Halu Oleo \\ E-mail: hermanmurhum2009@gmail.com \\ Handrawan \\ Pascasarjana Universitas Halu Oleo \\ E-mail: handrawansaranani84@gmail.com \\ Deity Yuningsih \\ Pascasarjana Universitas Halu Oleo \\ E-mail: deity.yuningsih@yahoo.com
}

\begin{abstract}
This study addressed at analyzing Judges' decision that ignored results of the social inquiry report, In addition, it is examining the legal impact at provisional of such a legal obligation in article 60 (3) and (4) Law Act 11 Year 2012 concerning Criminal Child System. This research applied legal research which focused on court decision toward the ignorance of social inquiry report. This study revealed that judges apparently ignore the social inquiry Report. The consequences of decision court are the verdict was declared null and void. Social inquiry reportis an important instrument in the juvenile criminal justice system based on the results of the research that has been done, the reason the judge did not include the results of the social inquiry report was because the social inquiry report had been considered but was not included in the verdict, The social inquiry report is only used as a reference material, the social research report has been attached as one unit in one case file, the social inquiry report is only included in the main points, and because judge more attention to the results of the social inquiry report. Then the legal implication of not including
\end{abstract}


the social inquiry report in the decision is that the decision becomes null and void, the case is reviewed and the decision is corrected by a higher court.

Keywords: Criminal Justice System; Community Research Report; Judge's Basis for Judgment;

Abstrak: Tujuan Penelitian ini untuk menganalisis alasan putusan hakim yang mengabaikan hasil laporan penelitian kemasyarakatan. Selain itu, menganalisis implikasi hukum terkait ketentuan frasa wajib yang dapat membuat putusan batal demi hukum dalam pasal 60 ayat (3) dan (4) Undang-Undang Nomor 11 Tahun 2012 tentang Sistem Peradilan Pidana Anak. Penelitian ini menggunakan penelitian hukum yang menitikberatkan pada putusan hakim yang tidak mencantumkan laporan penelitian kemasyarakatan dalam pertimbangan putusan hakim. Laporan penelitian kemasyarakatan merupakan instrumen penting dalam sistem peradilan pidana anak, hasil penelitian bahwa alasan hakim tidak mencantumkan laporan penelitian kemasyarakatan tersebut karena laporan penelitian kemasyarakatan telah dipertimbangkan tetapi tidak dimasukkan dalam putusan, laporan penelitian Kemasyarakatan hanya digunakan sebagai bahan referensi, laporan penelitian kemasyarakatan telah dilampirkan sebagai satu kesatuan dalam satu berkas perkara, laporan penelitian kemasyarakatan hanya dimasukkan dalam poin-poin penting, dan karena hakim lebih memperhatikan hasil laporan penelitian kemasyarakatan. Implikasi hukum tidak dicantumkannya laporan penelitian kemasyarakatan dalam putusan adalah putusan menjadi batal demi hukum, perkara ditinjau ulang dan putusan diperbaiki oleh pengadilan yang lebih tinggi.

Kata kunci: Sistem Peradilan Pidana Anak; Laporan Penelitian Kemasyarakatan; Dasar Pertimbangan Hakim;

\section{PENDAHULUAN}

Anak adalah tunas bangsa merupakan generasi penerus cita-cita perjuangan bangsa dan sumber daya manusia bagi pembangunan nasional serta harapan dan tumpuan orang tua, anak juga memiliki peran strategis, mempunyai ciri atau sifat khusus yang akan menjamin kelangsungan eksistensi bangsa dan negara di masa yang akan datang. Oleh karena itu, setiap anak haruslah mendapat pembinaan dan perlindungan dari sejak dini, anak perlu mendapat kesempatan yang seluas-luasnya untuk dapat tumbuh dan berkembang secara optimal, baik fisik, mental maupun sosial. Terlebih lagi bahwa masa kanak-kanak merupakan periode penabur benih, pendirian tiang pancang, pembuatan fondasi, yang dapat disebut juga sebagai periode pembentukan watak, kepribadian dan karakter diri seorang manusia, agar mereka kelak memiliki kekuatan dan kemampuan serta berdiri tegar dalam meniti kehidupan. ${ }^{1}$ Hal ini juga tercantum dalam penjelasan Undang-Undang Nomor

1 Maidin Gultom, Perlindungan Hukum Terhadap Anak Dalam Sistem Peradilan Anak di Indonesia, Bandung: Refika Aditama, 2008, hlm. 1. 
11 Tahun 2012 tentang Sistem Peradilan Pidana Anak, yaitu "anak adalah bagian yang tidak terpisahkan dari keberlangsungan hidup manusia dan keberlangsungan sebuah bangsa dan negara.

Salah satu bentuk perlindungan terhadap hak-hak anak adalah menjadikan peradilan pidana bagi anak sebagai langkah terakhir. Hakim sangat berperan dalam penjatuhan putusan pidana yang akan memberikan pengaruh terhadap apa yang akan di jalani oleh anak. Penjatuhan sanksi terhadap putusan yang ideal dapat memberikan rasa kepastian hukum dan rasa keadilan dalam masyarakat, meskipun sudah ada sebuah teori yang membenarkan di samping itu pula bahwa hakim dapat dikatakan sebagai corong undang-undang. ${ }^{2}$ Dalam menjatuhkan putusan hakim harus mempertimbangkan asas-asas sesuai yang di amanahkan dalam Undang-Undang Sistem Peradilan Pidana Anak Pasal 2 Undang-Undang SPPA yaitu pelindungan, keadilan, non diskriminasi, kepentingan terbaik bagi Anak, penghargaan terhadap pendapat Anak, kelangsungan hidup dan tumbuh kembang Anak.

Hakim dalam menjatuhkan putusan belum sepenuhnya memberikan putusan yang proporsional dan mengutamakan kepentingan yang terbaik bagi anak serta memperhatikan kesejahteraan anak, hakim sangat berperan dalam penjatuhan putusan pidana yang akan memberikan pengaruh terhadap apa yang akan di jalani oleh anak, pertimbangan hakim terhadap perkara pidana anak merupakan bagian penting yang menjadi dasar dalam menjatuhkan putusan termasuk Laporan Penelitian Kemasyarakatan yang di susun oleh Pembimbing Kemasyarakatan yang wajib di pertimbangkan oleh hakim.

Hakim berkewajiban untuk mempertimbangkan laporan penelitian kemasyarakatan sesuai yang tercantum pada Pasal 60 Ayat (3) dan Ayat (4) Undang-Undang SPPA menyebutkan bahwa: (3) Hakim wajib mempertimbangkan laporan penelitian kemasyarakatan dari pembimbing kemasyarakatan sebelum menjatuhkan putusan perkara. (4) Dalam hal laporan penelitian kemasyarakatan sebagaimana dimaksud pada ayat (3) tidak dipertimbangkan dalam putusan hakim, putusan batal demi hukum.

Dengan demikian, keberadaan Laporan Penelitian Kemasyarakatan (LITMAS) sangat penting sebagai dasar pertimbangan hakim dalam penjatuhan sanksi di samping fakta dan alat bukti dalam persidangan. Laporan Penelitian Kemasyarakatan merupakan laporan yang berisi hasil pengamatan yang dilakukan oleh Pembimbing Kemasyarakatan

2 Oheo K. Haris, "Telaah Yuridis Penerapan Sanksi Di Bawah Minimum Khusus Pada Perkara Pidana Khusus", Jurnal Ius Constituendum, Vol. 2 No. 2, 2017, hlm. 243. 
dimana secara umum menyampaikan data keseluruhan tentang anak yang berkonflik dengan hukum seperti data pribadi anak, keadaan keluarga anak, lingkungan hidup dan kehidupan sosial anak, dimana laporan penelitian kemasyarakatan tersebut akan merujuk kepada suatu analisis dan kesimpulan mengapa seorang anak melakukan suatu tindak pidana dan memberikan rekomendasi terkait putusan apa yang akan dijatuhkan oleh Hakim untuk kepentingan yang terbaik bagi anak, sehingga dari laporan penelitian kemasyarakatan tersebut dapat diketahui solusi terbaik untuk menyelesaikan perkara dan membina anak menjadi lebih baik melalui penjatuhan sanksi oleh Hakim dalam persidangan.

Berdasarkan putusan Hakim Pengadilan Negeri Kendari Nomor: 38/Pid.SusAnak/2019/PN Kdi tentang tindak pidana "melakukan kekerasan terhadap orang yang menyebabkan kematian" dalam putusan hakim telah memberikan pidana putusan yang dijatuhkan kepada terdakwa adalah pidana penjara selama 1 (satu) tahun 1 (satu) bulan berbeda dengan hasil rekomendasi laporan penelitian kemasyarakatan yang menyebutkan agar dapat diberikan sanksi pidana dengan syarat berupa pengawasan dan dalam putusan hakim tidak mencantumkan Laporan Penelitian Kemasyarakatan sebagai pertimbangkan hakim dalam memberikan putusan terhadap perkara anak tersebut. Sehingga sesuai Pasal 60 Ayat (3) Undang-undang SPPA terkait hakim wajib mempertimbangkan laporan penelitian kemasyarakatan telah diabaikan oleh hakim dalam putusan tersebut dan Ayat (4) disebutkan juga putusan batal demi hukum akan tetapi Putusan Hakim tetap dilaksanakan dan di eksekusi oleh Jaksa.

Berdasarkan uraian latar belakang masalah tersebut di atas, maka permasalahan pokok yang dikemukakan adalah sebagai berikut: Apakah Ratio Decidendi Putusan Hakim yang mengabaikan Laporan Penelitian Kemasyarakatan pada putusan Hakim Pengadilan Negeri Kendari Nomor: 38/Pid.Sus-Anak/2019/PN Kdi? dan Apakah ketentuan frasa wajib yang dapat membuat putusan batal demi hukum di dalam Pasal 60 Ayat (3) dan (4) UndangUndang No. 11 Tahun 2012 Tentang Sistem Peradilan Pidana Anak memiliki implikasi hukum atas putusan Hakim?

\section{METODE PENELITIAN}

Penelitian ini menggunakan tipologi penelitian hukum normatif khususnya yang berkaitan dengan tindak pidana yang dilakukan oleh anak. Hasil kajian norma-norma hukum dan melakukan wawancara dengan hakim sebagai responden sehingga dapat membantu untuk 
mendapatkan pandangan yang tepat tentang alasan hakim terhadap laporan penelitian kemasyarakatan sebagai dasar pertimbangan hakim dalam menjatuhkan putusan terhadap anak. Hal ini akan menjadi salah satu produk analisa abstraksi dari norma hukum positif. ${ }^{3}$ Peter Mahmud Marzuki, ${ }^{4}$ menyatakan bahwa penelitian hukum merupakan proses untuk menemukan aturan hukum, prinsip-prinsip hukum, maupun doktrin-doktrin hukum guna menjawab isu hukum yang dihadapi. Penelitian hukum normatif dilakukan untuk menghasilkan argumentasi, teori atau konsep baru sebagai gambaran dalam menyelesaikan masalah yang dihadapi. ${ }^{5}$ Penelitian ini menekankan pada analisis konsep ratio decidendi Hakim dalam penjatuhan putusan perkara anak dan pemahaman terkait Laporan Penelitian Kemasyarakatan Bapas.

Pendekatan-pendekatan yang digunakan di dalam penelitian hukum adalah pendekatan undang-undang (statute approach), Pendekatan konsep (Conceptual Approach) dan pendekatan kasus (case approach). Pendekatan Peraturan Perundang-undangan (Statute approach) yaitu dengan menelusuri setiap peraturan perundang-undangan yang mengatur mengenai putusan Hakim terhadap perkara anak. Pendekatan konseptual (Conseptual approach) yaitu gabungan antara asas hukum dan doktrin para ahli hukum pidana yang digunakan untuk memahami konsep hukum pidana terkait hakim dalam menjatuhkan putusan pidana terhadap anak dengan mempertimbangkan laporan hasil penelitian kemasyarakatan oleh Pembimbing Kemasyarakatan sebagai dasar dalam menjatuhkan putusan, sehingga diharapkan penormaan dalam aturan hukum dalam mengkaji serta menganalisis kerangka pikir atau kerangka konseptual maupun landasan teoritis sesuai dengan tujuan penelitian ini. Pendekatan kasus (Case approach) yaitu dengan melihat kasus anak yang berhadapan dengan hukum.

\section{ANALISIS DAN PEMBAHASAN}

Ratio Decidendi Putusan Hakim Yang Mengabaikan Laporan Penelitian Kemasyarakatan Pada Putusan Hakim Pengadilan Negeri Kendari Nomor: 38/Pid.Sus-Anak/2019/PN Kdi.

\section{Putusan Hakim Pengadilan Negeri Kendari Nomor: 38/Pid.Sus-Anak/2019/PN Kdi.}

Berdasarkan putusan Pengadilan Negeri Pengadilan Negeri Kendari Nomor: 38/Pid.Sus-

\footnotetext{
3 Soentandyo Wingyosoebroto, Penelitian Hukum, Surabaya: Pusat Studi Hukum dan Pembangunan Fakultas Hukum Unair, 1974, hlm. 1,7, dan 8.

4 Peter Mahmud Marzuki, Penelitian Hukum, Jakarta: Kencana, 2005, hlm. 35.

5 Yulianto Achmad, Mukti Fajar. Dualisme Penelitian Hukum Normatif \& Empiris, Yogyakarta: Pustaka Pelajar, 2010. hlm. 48.
} 
Anak/2019/PN. Kdi Tentang Tindak Pidana "Melakukan Kekerasan Terhadap Orang Yang Menyebabkan Kematian" yang mengadili perkara pidana anak dengan acara pemeriksaan biasa dalam tingkat pertama menjatuhkan putusan sebagai berikut dalam perkara Anak MUSRAN BIN RAUF, pembacaan tuntutan pidana yang diajukan oleh Penuntut Umum yang pada pokoknya sebagai berikut menyatakan Anak MUSRAN Bin RAUF telah terbukti secara sah dan meyakinkan bersalah melakukan tindak pidana "dengan terang-terangan dan dengan tenaga bersama menggunakan kekerasan terhadap orang atau barang", sebagaimana diatur dan diancam pidana dalam Pasal 170 ayat (2) ke-3 KUHP pada Dakwaan Kedua. menjatuhkan pidana terhadap Anak MUSRAN Bin RAUF dengan pidana penjara selama 2 (dua) tahun dikurangi masa penahanan yang telah dijalani oleh Anak, dengan perintah agar Anak tersebut tetap ditahan. Menetapkan agar Anak dibebani membayar biaya perkara sebesar Rp 2.000,- (dua ribu rupiah).

Berdasarkan pertimbangan hakim dan Memperhatikan, Pasal 170 ayat (2) ke 3 KUHP, Undang-undang Nomor 11 Tahun 2012 tentang Sistem Peradilan Pidana Anak dan Undang-Undang Nomor 8 Tahun 1981 tentang Hukum Acara Pidana serta peraturan perundang-undangan lain yang bersangkutan, Hakim menjatuhkan putusan anak MUSRAN BIN RAUF terbukti secara sah dan meyakinkan bersalah melakukan tindak pidana “melakukan kekerasan terhadap orang yang menyebabkan kematian”, menjatuhkan pidana kepada anak MUSRAN BIN RAUF dengan pidana penjara selama 1 (satu) tahun 1 (satu) bulan; MUSRAN BIN RAUF, menetapkan masa penangkapan dan penahanan yang telah dijalani anak MUSRAN BIN RAUF dikurangkan seluruhnya dari pidana yang dijatuhkan, menetapkan Anak MUSRAN BIN RAUF tetap berada di dalam tahanan dan membebankan kepada Anak untuk membayar biaya perkara sejumlah Rp 2.000,- (dua ribu rupiah). Dalam putusan sebagai Hakim Ketua I Ketut Pancaria, S.H., Hakim Anggota Irmawati Abidin, S.H., M.H. dan Tahir, S.H., M.H.

\section{Alasan Hakim Yang Mengabaikan Hasil Laporan Penelitian Kemasyarakatan Sebagai Dasar Pertimbangan Dalam Putusan Perkara Pidana Anak Nomor: 38/Pid.Sus- Anak/2019/PN Kdi.}

Menurut Irmawati Abidin Hakim pada Pengadilan Negeri Kendari laporan penelitian kemasyarakatan merupakan dasar yang vital untuk pembuktian hakim, tapi tidak bisa menentukan atau mengarahkan hakim dalam menjatuhkan putusan sebagaimana saran laporan penelitian kemasyarakatan. Karena laporan penelitian kemasyarakatan bukan pro 
justicia dalam pengertian proses hukum. Laporan penelitian kemasyarakatan lebih bersifat sosial atau berisi pertimbangan sosial, bukan pertimbangan keadilan dan pertimbangan hukum, hakim dalam menjatuhkan putusan tidak semata-mata pada laporan penelitian kemasyarakatan tetapi tetap memperhatikan fakta-fakta persidangan.

Berdasarkan 2 responden yaitu hakim anak Pengadilan Negeri Kendari memberikan alasan sebagai berikut:

a. Sudah dipertimbangkan, tetapi tidak dicantumkan dalam putusan

Mempertimbangkan dalam pasal tersebut bukan berarti mencantumkan atau menuliskan hasil laporan penelitian kemasyarakatan. Hakim tetap mendengarkan dan mempertimbangkan hasil LITMAS yang disampaikan oleh Pembimbing Kemasyarakatan Bapas, namun mencantumkan atau tidak mencantumkan hasil laporan penelitian kemasyarakatan bukan menjadi persoalan. ${ }^{6}$

Selain itu dalam Undang-Undang tidak dijelaskan secara jelas, apakah LITMAS itu harus dicantumkan. Sehingga pengertian masing-masing terhadap kata "mempertimbangkan" juga berbeda. Apakah mempertimbangkan berarti dicantumkan dalam putusan atau hanya dipertimbangkan tanpa harus dicantumkan. Apakah hanya menjadi patokan saja atau wajib dicantumkan secara nyata tertulis di dalam putusan. Sehingga menurut hakim dapat dicantumkan secara eksplisit saja dalam putusan. ${ }^{7}$

Sehingga dapat dinyatakan bahwa tidak mengikat apakah LITMAS harus dicantumkan, yang penting dipertimbangkan dan disebut dalam putusan bahwa hakim telah mempertimbangkan LITMAS tersebut. Sebenarnya sudah dipertimbangkan, sehingga walaupun tidak ditulis bukan berarti tidak dipertimbangkan. ${ }^{8}$

b. LITMAS hanya digunakan sebagai bahan referensi

LITMAS dapat menjadi bahan referensi hakim untuk putusan karena hakim tidak bisa melihat kondisi anak sehingga Laporan Penelitian Kemasyarakatan salah satu referensi hakim untuk mendapatkan informasi terkait anak, sampai dimana anak tersebut bisa dipidana, pantasnya dipidana berapa lama. Bagaimana keadaan anak, keluarga anak, lingkungan anak, dan hal-hal yang

Hasil Wawancana dengan I Ketut Pancaria, Hakim Pengadilan Negeri Kendari.

7 Hasil Wawancana dengan I Ketut Pancaria, Hakim Pengadilan Negeri Kendari.

8 Hasil Wawancana dengan I Ketut Pancaria, Hakim Pengadilan Negeri Kendari. 
berkaitan dengan kehidupan anak. Dari LITMAS hakim mendapat gambaran bagaimana terdakwa itu sebenarnya. Karena pada dasarnya dalam memutus perkara hakim tidak hanya bekerja berdasar pada text book, akan tetapi terdapat unsur pertimbangan moral justice, social justice dan legal justice sehingga ketiga unsur tersebut harus saling bersinergi. Sementara itu LITMAS sebagai bagian dari social justice tidak harus dituangkan dalam suatu pertimbangan, namun tetap menjadi pedoman atau guidance hakim untuk menjatuhkan putusan tindak pidana yang pelakunya anak. ${ }^{9}$

Kemudian menurut hakim, dalam memutus perkara yang utama adalah fakta-fakta di persidangan, sehingga peran LITMAS hanya sebagai pembantu dalam memeriksa perkara anak. Karena bagaimanapun dalam hukum pidana yang dicari adalah kebenaran materiil. ${ }^{10}$

c. LITMAS telah dilampirkan menjadi satu kesatuan dalam satu berkas perkara LITMAS telah dilampirkan dalam berkas perkara, sehingga ketika ada seseorang membaca putusan hakim kemudian bertanya mengapa hakim memutus perkara tersebut demikian, maka dapat dibaca bagaimana hasil LITMAS yang terlampir dalam berkas perkara. Karena LITMAS telah terlampir di berkas. Dan dapat langsung dibaca secara lengkap di berkas. Sehingga tidak masalah apakah hasil laporan penelitian kemasyarakatan dicantumkan atau tidak, karena LITMAS tersebut sudah termasuk satu paket dalam berkas perkara. ${ }^{11}$

d. LITMAS dalam putusan hanya dicantumkan pokok-pokoknya saja Dikarenakan isi LITMAS yang terlalu banyak yaitu rata-rata 5-6 halaman. sehingga agar isi putusan lebih efisien, maka LITMAS hanya dibaca dan di rangkum. Rangkuman dari LITMAS tersebut sekiranya yang menjadi dasar atau faktor dilakukannya tindak pidana. Jadi hanya pokok-pokoknya saja. Biasanya hakim dalam putusan menulis "menimbang bahwa sebelum majelis hakim menjatuhkan putusan telah terlebih dahulu mempertimbangkan LITMAS yang dibuat oleh Bapas nomor.... tanggal... atas nama terdakwa... yang pada pokoknya sebagai berikut...." Kemudian dimuatlah pokok-pokok dari laporan penelitian kemasyarakatan. Walaupun tidak semua harus

9 Hasil Wawancana dengan Irmawati Abidin, Hakim Pengadilan Negeri Kendari.

10 Hasil Wawancana dengan Irmawati Abidin, Hakim Pengadilan Negeri Kendari.

11 Hasil Wawancana dengan Irmawati Abidin, Hakim Pengadilan Negeri Kendari. 
dicantumkan, tapi secara garis besar harus dimasukkan dalam putusan. Artinya dari rangkuman bisa mencakup semua isi LITMAS tersebut. ${ }^{12}$

e. Lebih memperhatikan pada hasil LITMAS

Masalah mencantumkan atau tidak mencantumkan hasil LITMAS dalam dasar pertimbangan adalah terpenting apakah hakim akan mengikuti saran dari laporan penelitian tersebut atau tidak. Dan hakim harus memberikan alasan terhadap keputusan tersebut. Sehingga paling tidak mencantumkan hasil atau kesimpulan dan saran dari laporan penelitian kemasyarakatan tersebut. Terkait dengan hasil laporan penelitian kemasyarakatan mengenai faktor anak melakukan tindak pidana, sebenarnya hal tersebut sudah terdapat dalam proses persidangan yang diperoleh dari keterangan terdakwa, korban dan saksi-saksi di persidangan. Selain itu untuk menghindari pandangan subjektif dari laporan penelitian kemasyarakatan dari pembimbing kemasyarakatan. ${ }^{13}$

\section{Implikasi Hukum Atas Putusan Hakim Di Dalam Pasal 60 Ayat (3) Dan (4) Undang-} Undang Nomor 11 Tahun 2012 Tentang Sistem Peradilan Pidana Anak Terkait Ketentuan Frasa Wajib Yang Dapat Membuat Putusan Batal Demi Hukum

Ketentuan Frasa Wajib Yang Dapat Membuat Putusan Batal Demi Hukum Di Dalam Pasal 60 Ayat (3) Dan (4) Undang-Undang No. 11 Tahun 2012 Tentang Sistem Peradilan

\section{Pidana Anak}

\section{Ketentuan Frasa Wajib}

Dalam peraturan perundangan-undangan sering ditemukan kata dapat, harus, atau wajib, ketiganya berimplikasi dan memiliki makna yang berbeda. Deputi Direktur Yayasan SET, Agus Sudibyo, Agus menyayangkan kebiasaan pembentuk Undang-Undang menuliskan frasa "cukup jelas" pada bagian penjelasan. Kebiasaan ini justru menyulitkan pihak lain memahami apa yang dimaksud dalam suatu rumusan. Pihak lain sebenarnya bisa mencari latar belakang dan perdebatan (memorie van toelichting) mengenai rumusan tersebut, atau suasana kebatinan lahirnya suatu rumusan. ${ }^{14}$

Dalam Pasal 60 Ayat 3 Undang-Undang SPPA terkait adanya ketentuan frasa kata

12 Hasil Wawancana dengan Irmawati Abidin, Hakim Pengadilan Negeri Kendari.

13 Hasil Wawancana dengan I Ketut Pancaria, Hakim Pengadilan Negeri Kendari.

14 "Bahasa Hukum", Dukun Hukum, https://dukunhukum.wordpress.com/2012/06/11/bahasa-hukum/, diakses pada tanggal 10 Oktober 2020. 
"wajib" dalam penjelasan Undang-Undang pada ayat 3 dinyatakan "cukup jelas" sehingga dapat menyulitkan pemahaman terkait kata wajib tersebut apakah harus atau dapat di abaikan walaupun sebenarnya Menurut Kamus Besar Bahasa Indonesia (KBBI) kata 'wajib' mengandung arti "harus dilakukan, tidak boleh tidak dilaksanakan" akan tetapi perlu pendalaman pemahaman terkait kata "wajib" dalam bahasa hukum.

Tetapi, di mata Pengajar Fakultas Hukum Universitas Indonesia Fernando Manullang, teks hukum selalu terbuka akan interpretasi. Se-rigid apa pun kata yang dipilih atau bahasa yang dirumuskan dalam suatu Undang-Undang, masih tetap terbuka kemungkinan penafsiran berbeda oleh orang yang berbeda. ${ }^{15}$

\section{Putusan Batal Demi Hukum}

Pasal 60 ayat (4) UU SPPA menyatakan bahwa dalam hal laporan penelitian kemasyarakatan tidak dipertimbangkan dalam putusan hakim, putusan batal demi hukum. Menurut penjelasan dalam UU SPPA “batal demi hukum dalam ketentuan ini adalah tanpa dimintakan untuk dibatalkan dan putusan tidak mempunyai kekuatan hukum yang mengikat".

Sebuah ketetapan yang tidak sah menurut Utrecht, mengenal tiga macam yakni:

1. Batal (nietig/absolute nietig);

2. Batal demi hukum (nietigheid van rechtswege);

3. Dapat dibatalkan (verniegbaar).

Ketetapan yang batal (neitig/absolute nietig) berarti bagi hukum perbuatan yang dilakukan dianggap tidak ada. bagi hukum, akibat perbuatan hukum itu tidak ada sejak semula. Sedangkan batal karena hukum atau batal demi hukum (nietigheid van rechtswege) berakibat suatu perbuatan untuk sebagian atau keseluruhan bagi hukum dianggap tidak pernah ada (dihapuskan) tanpa diperlukan suatu keputusan hakim atau keputusan suatu badan pemerintahan batalnya sebagian atau seluruh akibat ketetapan itu.

Mengenai putusan batal demi hukum dijelaskan oleh Yahya Harahap dalam bukunya Pembahasan, Permasalahan dan Penerapan KUHAP: Pemeriksaan Sidang Pengadilan, Banding, Kasasi, dan Peninjauan Kembali (h. 385). Arti putusan batal demi hukum, berakibat putusan yang dijatuhkan:

1. Dianggap "tidak pernah ada" atau never existed sejak semula;

2. Putusan yang batal demi hukum tidak mempunyai kekuatan dan akibat 
hukum;

Dengan demikian putusan yang batal demi hukum, sejak semula putusan itu dijatuhkan sama sekali tidak memiliki daya eksekusi atau tidak dapat dilaksanakan, oleh karena itu putusan yang batal demi hukum adalah putusan yang sejak semula dijatuhkan, putusan itu dianggap tidak pernah ada, tidak mempunyai kekuatan dan akibat hukum, serta tidak memiliki daya eksekusi.

Syarat yang harus dimuat dalam sebuah putusan hakim diatur dalam Pasal 197 Undang-Undang Nomor 8 Tahun 1981 tentang Hukum Acara Pidana ("KUHAP”) yang berbunyi:

(1) Surat putusan pemidanaan memuat:

a. kepala putusan yang dituliskan berbunyi: "DEMI KEADILAN BERDASARKAN KETUHANAN YANG MAHA ESA";

b. nama lengkap, tempat lahir, umur atau tanggal, jenis kelamin, kebangsaan, tempat tinggal, agama dan pekerjaan terdakwa;

c. dakwaan, sebagaimana terdapat dalam surat dakwaan;

d. pertimbangan yang disusun secara ringkas mengenai fakta dan keadaan beserta alat-pembuktian yang diperoleh dari pemeriksaan di sidang yang menjadi dasar penentuan kesalahan terdakwa;

e. tuntutan pidana, sebagaimana terdapat dalam surat tuntutan;

f. pasal peraturan perundang-undangan yang menjadi dasar pemidanaan atau tindakan dan pasal peraturan perundang-undangan yang menjadi dasar hukum dari putusan, disertai keadaan yang memberatkan dan yang meringankan terdakwa;

g. hari dan tanggal diadakannya musyawarah majelis hakim kecuali perkara diperiksa oleh hakim tunggal;

h. pernyataan kesalahan terdakwa, pernyataan telah terpenuhi semua unsur dalam rumusan tindak pidana disertai dengan kualifikasinya dan pemidanaan atau tindakan yang dijatuhkan;

i. ketentuan kepada siapa biaya perkara dibebankan dengan menyebutkan jumlahnya yang pasti dan ketentuan mengenai barang bukti;

j. $\quad$ keterangan bahwa seluruh surat ternyata palsu atau keterangan di mana letaknya kepalsuan itu, jika terdapat surat otentik dianggap palsu;

k. perintah supaya terdakwa ditahan atau tetap dalam tahanan atau dibebaskan;

l. hari dan tanggal putusan, nama penuntut umum, nama hakim yang memutus dan nama panitera;

(2) Tidak dipenuhinya ketentuan dalam ayat (1) huruf a, b, c, d, e, f, h, j, k dan l pasal ini mengakibatkan putusan batal demi hukum;

(3) Putusan dilaksanakan dengan segera menurut ketentuan dalam undangundang ini.

Putusan yang batal demi hukum adalah putusan yang lupa mencantumkan salah satu ketentuan huruf a, b, c, d, e, f, h, j, k dan l, berarti putusan dianggap tidak pernah ada dan 
tidak mempunyai kekuatan hukum terhadap terdakwa serta jaksa tidak dapat melaksanakannya. ${ }^{16}$

Bahwa yang batal demi hukum hanya terbatas "sepanjang putusan" saja. Yang dimaksud Pasal 197 ayat (2) KUHAP putusan batal demi hukum, tidak lebih dari putusan yang dijatuhkan. Yang mengandung cacat dan kekeliruan terbatas pada putusan yang dijatuhkan. Sedang pemeriksaan atau berita acara pemeriksaan tetap sah dan mempunyai kekuatan hukum. ${ }^{17}$

Oleh karena berita acara pemeriksaan tetap sah dan berharga, pengadilan dapat mempergunakan sebagai landasan untuk menjatuhkan putusan yang sah sesuai dengan yang dikehendaki Pasal 197 ayat (1) KUHAP. Pendapat ini didasarkan pada rumusan ketentuan Pasal 197 ayat (2) itu sendiri, yang menegaskan bahwa kelalaian pengadilan memenuhi ketentuan Pasal 197 ayat (1) mengakibatkan "putusan" batal demi hukum. Jadi, yang batal demi hukum adalah putusan yang dijatuhkan. ${ }^{18}$ Jadi yang batal demi hukum itu adalah sebatas putusannya saja.

\section{Pihakyang Berhak Menyatakan Putusan Batal Demi Hukum}

Pernyataan batal demi hukum dilakukan instansi pengadilan yang lebih tinggi. Pendapat ini bertitik tolak dari ajaran yang berpendirian sifat batal demi hukum (van rechtsweenietig) atau null and void tidak murni dan tidak mutlak. Sekalipun undang-undang merumuskan sesuatu batal demi hukum, namun keadaan batal demi hukum tidak dengan sendirinya terjadi. Untuk itu harus ada pernyataan resmi dari instansi yang lebih tinggi. ${ }^{19}$

Jadi, agar suatu putusan yang batal demi hukum benar-benar resmi batal secara formal, diperlukan tindakan dari pihak lain, dalam hal ini instansi pengadilan yang lebih tinggi atau dari instansi yang berwenang. ${ }^{20}$

Dengan demikian sifat putusan yang batal demi hukum pada hakikatnya berubah menjadi dapat dibatalkan atau dinyatakan batal atau voidable oleh instansi yang lebih tinggi atau instansi yang berwenang. ${ }^{21}$ Pernyataan putusan batal demi hukum dapat diajukan oleh: $^{22}$

16 Yahya Harahap, Pembahasan, Permasalahan dan Penerapan KUHAP: Pemeriksaan Sidang Pengadilan, Banding, Kasasi, dan Peninjauan Kembali, Jakarta: Sinar Grafika, 2015, hlm. 385.

17 Ibid., hlm. 386.

18 Ibid.

19 Ibid., hlm. 387.

20 Ibid.

21 Ibid.

22 Ibid., hlm. 388. 

a. Terdakwa;
b. Penasihat hukum; dan
c. Jaksa.

Yahya menegaskan pembatalan putusan pengadilan yang bersifat mutlak ini tidak melihat apakah itu putusan tingkat pertama, banding, atau kasasi. Putusan itu tetap dianggap sebagai putusan yang tidak sah dan tidak pernah ada, sehingga tidak memiliki kekuatan daya hukum mengikat (eksekutorial) kepada terpidana. Menurut ahli yang dihadirkan pemohon ini, apabila jaksa tetap mengeksekusi putusan batal demi hukum berarti jaksa telah bertindak sewenang-wenang, inkonstitusional, dan melanggar HAM. "Eksekusi terhadap putusan yang batal demi hukum nyata-nyata melanggar pilar negara hukum karena melanggar Pasal 1 ayat (3), Pasal 28D ayat (1), Pasal 28J ayat (1) UUD 1945," tutur Yahya. ${ }^{23}$

\section{Implikasi Hukum Atas Putusan Hakim Yang Mengabaikan Hasil Laporan Penelitian Kemasyarakatan Sebagai Dasar Pertimbangan Hakim Dalam Putusan Perkara \\ Pidana Anak}

Profil Pembimbing Kemasyarakatan Menurut Peraturan Perundang-Undangan dan Menurut Ahli

Sejak berdirinya Lembaga Reklasering di Indonesia pada zaman Pemerintahan Belanda, petugas yang menjadi garda terdepan dalam pelayanan hukum kepada masyarakat saat itu dikenal dengan sebutan Ambtenaar der Reclassering disebut juga Bijzondere Ambtenaar (Pegawai Negeri Istimewa) atau dalam bahasa Inggris disebut Probation Officer, Pekerja Sosial Kehakiman dan mulai 1968 petugas tersebut dikenal dengan sebutan Pembimbing Kemasyarakatan. Tugas dan tanggung jawabnya telah diatur dalam Wetboek van strafrecht yang kemudian dilakukan perubahan dalam KUHP pada 1917 yang diberlakukan mulai 1 Januari 1918. Dalam pasal 14. d. (2). KUHP disebutkan bahwa "Hakim boleh mewajibkan kepada seseorang Ambtenaar istimewa, supaya memberi pertolongan dan bantuan kepada sistem hukum tentang perjanjian istimewa itu"

Keberadaan Pembimbing Kemasyarakatan kemudian diperkuat juga oleh Hakim Agung wanita pertama di Indonesia, Sri Widoyati, W.S., SH. dalam Surat Edaran Hakim Agung tanggal 4 Juli 1971 nomor M.A./PEM/040/1971. tentang “sidang perkara anak” yang menyebutkan bahwa dalam sidang anak: a) Harus hadir pekerja sosial dan b) Harus ada

23 Ibid. 
laporan data sosial. Melalui surat edaran inilah maka hingga kini keberadaan PK dalam persidangan menjadi penting, baik secara legal formal maupun secara aktual. Hal ini ditujukan agar petugas penegak hukum lainnya mendapat second opinion (pendapat pihak lain) mengenai latar belakang anak yang dalam proses hukum agar keputusan hukum yang diambil tepat sasaran karena berkaitan dengan masa depan anak.

Pembimbing Kemasyarakatan mempunyai tugas khusus dalam proses penegakan hukum. Pembimbing Kemasyarakatan merupakan salah satu bagian dari sistem tata peradilan pidana, seperti halnya Polisi, Jaksa, Hakim, dan Pengacara. ${ }^{24}$

Undang-Undang Nomor 11 Tahun 2012 tentang Sistem Peradilan Pidana Anak Pasal 13 menyebutkan bahwa Pembimbing Kemasyarakatan adalah pejabat fungsional penegak hukum yang melaksanakan penelitian kemasyarakatan, pembimbingan, pengawasan, dan pendampingan terhadap Anak di dalam dan di luar proses peradilan pidana. Dalam melaksanakan tugasnya seorang Pembimbing Kemasyarakatan mempunyai kewajiban sesuai yang diatur dalam Keputusan Menteri Kehakiman RI No.: M.01-PK.04.10 Tahun 1998 tentang Tugas, Kewajiban, dan Syarat-syarat bagi Pembimbing Kemasyarakatan, antara lain adalah sebagai berikut.

a. Menyusun laporan atas hasil penelitian kemasyarakatan yang telah dilakukannya atau dikenal dengan nama Laporan Penelitian Kemasyarakatan (LITMAS);

b. Mengikuti sidang Tim Pengamat Pemasyarakatan guna memberikan data, saran, dan pertimbangan atas hasil penelitian dan pengamatan yang telah dilakukannya;

c. Mengikuti sidang pengadilan yang memeriksa perkara Anak Nakal guna memberikan penjelasan, saran dan pertimbangan kepada hakim mengenai segala sesuatu yang berkaitan dengan Anak Nakal yang sedang diperiksa di Pengadilan berdasarkan hasil penelitian kemasyarakatan yang telah dilakukannya;

d. Melakukan Pendampingan, Pembimbingan, dan pengawasan terhadap Anak dalam proses Sistem Peradilan Anak;

e. Melaporkan setiap pelaksanaan tugas kepada Kepala Balai Pemasyarakatan.

24 Ibid., hlm. 6. 


\section{Prosedur dan Mekanisme Laporan Penelitian Kemasyarakatan}

Penelitian Kemasyarakatan adalah kegiatan penelitian untuk mengetahui latar belakang kehidupan warga binaan pemasyarakatan yang dilaksanakan oleh Balai Pemasyarakatan (PP 31 Tahun 1999: Pasal 1 angka 3). Data yang diungkap tersebut dituangkan dalam bentuk suatu laporan yang sekarang dikenal dengan nama Laporan Penelitian Kemasyarakatan (Litmas). Laporan tersebut harus dipertanggungjawabkan di depan sidang peradilan baik secara tertulis maupun lisan. Dalam perkembangan selanjutnya Laporan Penelitian Kemasyarakatan (Litmas) digunakan juga untuk proses pembinaan warga binaan pemasyarakatan di Lembaga Pemasyarakatan maupun di Rumah Tahanan Negara yaitu untuk Litmas tahap awal, Litmas CMK, Litmas asimilasi, Litmas untuk CMB, CB, dan PB. Prosedur dan mekanisme Penelitian Kemasyarakatan yang ditempuh oleh Pembimbing Kemasyarakatan sebagai berikut:

a. Pencatatan (registrasi) permintaan Litmas.

b. Pengumpulan data dengan cara memanggil, dan atau mengunjungi rumah dan tempat-tempat lain yang berhubungan dengan permasalahan klien. Untuk memperoleh data tersebut, pembimbing kemasyarakatan mempergunakan teknik-teknik sebagai berikut: pengamatan, wawancara, psikotes, mempelajari dokumen-dokumen yang berhubungan dengan permasalahan dan teknik-teknik lainnya.

c. Pengolahan data, setelah memperoleh data-data yang lengkap, pembimbing kemasyarakatan menganalisis dan menyimpulkan serta memberikan pertimbangan atau saran sehubungan dengan permasalahannya yang selanjutnya dituangkan dalam Konsep laporan penelitian kemasyarakatan.

d. Sidang TPP, konsep Litmas yang telah dibuat kemudian dibahas dalam forum sidang Tim Pengamat Pemasyarakatan untuk mendapatkan tanggapan dari peserta sidang serta menentukan saran dan pertimbangan dari Litmas.

e. Perbaikan dan Penggandaan Litmas, Penandatanganan serta pengiriman Litmas.

Implikasi Hukum Atas Putusan Hakim Yang Mengabaikan Hasil Laporan Penelitian Kemasyarakatan Sebagai Dasar Pertimbangan Hakim Dalam Perkara Anak.

Implikasi hukum dari tidak dicantumkannya hasil laporan penelitian kemasyarakatan adalah sebagai berikut: 
a. Putusan menjadi batal demi hukum

Ketika hakim tidak mempertimbangkan LITMAS dalam putusan, maka hal tersebut sesuai Undang-Undang tentu batal demi hukum. Batal demi hukum berarti putusan tersebut dianggap tidak pernah ada (never existed). ${ }^{25}$ Yang dimaksud putusan batal demi hukum, apabila putusan tersebut tidak memenuhi syarat-syarat sebagaimana ditentukan dalam Pasal 197 ayat (1) KUHAP. ${ }^{26}$ Dalam hal perkara pidana anak, berlaku pula ketentuan Pasal 60 ayat (3) dan ayat (4) UU SPPA yang mengatur secara khusus tentang laporan penelitian kemasyarakatan, namun tetap mengacu juga kepada KUHAP selama Undang-Undang Nomor 11 Tahun 2012 tidak mengaturnya.

Putusan pengadilan dikatakan "batal demi hukum" (venrechtswege nietig atau ab initio legally null and void) artinya putusan tersebut sejak semula dianggap tidak pernah ada (never existed). Karena tidak pernah ada, maka putusan demikian itu tidak mempunyai venrechtswege nietig atau ab initio legally null and void kekuatan hukum dan tidak membawa akibat hukum, sehingga dengan demikian, putusan tersebut dengan sendirinya tidak dapat dieksekusi atau dilaksanakan oleh Jaksa sebagai eksekutor putusan pengadilan. ${ }^{27}$ Akan tetapi selama ini batal demi hukum secara praktik belum pernah terjadi. Hingga saat ini secara praktik putusan hakim meskipun dengan tidak mempertimbangkan dan mencantumkan LITMAS, putusan itu tidak serta merta menjadi batal demi hukum. Dan pada kenyataannya putusan hakim selama ini dapat dieksekusi.

b. Perkara diperiksa ulang dan putusan diperbaiki

Salah satu bentuk batal demi hukum yaitu perkara yang diajukan melalui upaya hukum dapat diperiksa ulang dengan mempertimbangkan LITMAS oleh pengadilan yang lebih tinggi kemudian mengeluarkan putusan lagi. Putusan sebelumnya diperbaiki dengan dicantumkannya hasil LITMAS dalam putusan sebagai dasar pertimbangan. ${ }^{28}$

25 Hasil Wawancana dengan Irmawati Abidin, Hakim Pengadilan Negeri Kendari,

26 Fachmi, Kepastian Hukum Mengenai Putusan Batal Demi Hukum dalam Sistem Peradilan Pidana Indonesia, Bogor: Ghalia Indonesia publishing, 2011, hlm.163

27 Yusril Ihza Mahendra, "Pendapat Hukum Terhadap Putusan Batal Demi Hukum", Yusril Ihza Mahendra, http://yusril.ihzamahendra.com/2012/05/17/pendapat-hukum-terhadap-putusan-batal-demihukum/, diakses pada tanggal 10 Oktober 2020.

28 Hasil Wawancana dengan Irmawati Abidin, Hakim Pengadilan Negeri Kendari. 
Putusan yang batal demi hukum tidak mempunyai alternatif lain selain harus diperbaiki atau harus disempurnakan. Yang menjadi permasalahan adalah kewenangan untuk memperbaiki atau menyempurnakan. Sebagian pakar berpendapat bahwa majelis hakim yang menjatuhkan putusan tersebutlah yang harus mengubah, sebagian lagi berpendapat bahwa pengadilan yang lebih tinggi yang menyatakan batal demi hukum dan yang berwenang memperbaiki. Kedua pandangan dan pendapat tersebut tidak didukung oleh dasar hukum dan alasan/pertimbangan yang kuat. ${ }^{29}$

\section{KESIMPULAN}

Alasan hakim yang mengabaikan hasil laporan penelitian kemasyarakatan sebagai dasar pertimbangan dalam putusan adalah dalam memeriksa dan memutus perkara menyatakan telah mempertimbangkan laporan penelitian kemasyarakatan, akan tetapi tidak mencantumkan kutipan hasil laporan penelitian kemasyarakatan tersebut dalam putusan. Laporan penelitian kemasyarakatan digunakan sebagai referensi atau pedoman dalam memeriksa dan memutus perkara. Laporan penelitian kemasyarakatan telah terlampir dalam berkas perkara. Hakim hanya mencantumkan pokok-pokok dari laporan penelitian kemasyarakatan. faktor-faktor anak melakukan tindak pidana telah diketahui melalui proses pemeriksaan di persidangan. Implikasi hukum atas putusan hakim di dalam Pasal 60 Ayat (3) dan (4) Undang-Undang Nomor 11 Tahun 2012 terkait ketentuan frasa wajib yang dapat membuat putusan batal demi hukum adalah putusan yang tidak mencantumkan hasil laporan penelitian kemasyarakatan sebagai pertimbangan hakim menjadi batal demi hukum, sesuai KUHAP Pasal 197 Ayat (1) dan pasal 60 ayat (4) UU SPPA. Terhadap putusan yang tidak mencantumkan hasil laporan penelitian kemasyarakatan dapat dilakukan pemeriksaan ulang dan perbaikan terhadap putusan oleh pengadilan yang lebih tinggi karena putusan tidak pernah batal dengan sendirinya walaupun dalam Undang-Undang di nyatakan batal demi hukum.

\section{Daftar Pustaka}

\section{Buku}

Achmad, Yulianto, Mukti Fajar. Dualisme Penelitian Hukum Normatif \& Empiris, Yogyakarta: Pustaka Pelajar, 2010.

29 Leden Marpaung, Proses Penanganan Perkara Pidana: Di Kejaksaan Dan Pengadilan Negeri Upaya Hukum Dan Eksekusi, Jakarta: Sinar Grafika, 2010, hlm. 146 
Fachmi, Kepastian Hukum Mengenai Putusan Batal Demi Hukum dalam Sistem Peradilan Pidana Indonesia, Bogor: Ghalia Indonesia Publishing, 2011.

Gultom, Maidin, Perlindungan Hukum Terhadap Anak Dalam Sistem Peradilan Anak di Indonesia, Bandung: Refika Aditama, 2008.

Harahap, Yahya, Pembahasan, Permasalahan dan Penerapan KUHAP: Pemeriksaan Sidang

Pengadilan, Banding, Kasasi, dan Peninjauan Kembali, Jakarta: Sinar Grafika, 2015. Marpaung, Leden, Proses Penanganan Perkara Pidana: Di Kejaksaan Dan Pengadilan Negeri Upaya Hukum Dan Eksekusi, Jakarta: Sinar Grafika, 2010.

Marzuki, Peter Mahmud, Penelitian Hukum, Jakarta: Kencana, 2005.

Wingyosoebroto, Soentandyo, Penelitian Hukum, Surabaya: Pusat Studi Hukum dan Pembangunan Fakultas Hukum Unair, 1974.

\section{Jurnal}

Haris, Oheo K., “Telaah Yuridis Penerapan Sanksi Di Bawah Minimum Khusus Pada Perkara Pidana Khusus", Jurnal Ius Constituendum, Vol. 2 No. 2, 2017.

\section{Peraturan Perundang-undangan}

Undang-Undang Negara Republik Indonesia Nomor 8 tahun 1981 tentang Kitab UndangUndang Hukum Acara Pidana.

Undang-Undang Negara Republik Indonesia Nomor 11 Tahun 2012 Tentang Sistem Peradilan Pidana Anak.

Keputusan Menteri Kehakiman RI Nomor M.01-PK.04.10 Tahun 1998 tentang Tugas, Kewajiban, dan Syarat-syarat bagi Pembimbing Kemasyarakatan.

Putusan Hakim Pengadilan Negeri Kendari Nomor : 38/Pid.Sus-Anak/2019/PN Kdi.

\section{Situs web}

"Bahasa Hukum", Dukun Hukum, https://dukunhukum.wordpress.com/2012/06/11/ bahasa-hukum/, diakses pada tanggal 10 Oktober 2020.

Mahendra, Yusril Ihza, "Pendapat Hukum Terhadap Putusan Batal Demi Hukum”, Yusril Ihza Mahendra, http://yusril.ihzamahendra.com/2012/05/17/pendapat-hukumterhadap-putusan-batal-demi-hukum/ , diakses pada tanggal 10 Oktober 2020. 